\title{
Design for Control: Surgery, Science, and Space at the Royal Victoria Hospital, Montreal, 1893-1956
}

\author{
ANNMARIE ADAMS and THOMAS SCHLICH*
}

\section{Introduction}

In this paper we explore the relationship of modern architecture and modern surgery in the twentieth century. Our central argument is that environments designed for surgery in the modern hospital became more like laboratories at the end of a remarkable metamorphosis, which we explain through three distinct types of spaces in a particularly significant case study, the Royal Victoria Hospital (RVH) in Montreal, Quebec. ${ }^{1}$ As the changing design of surgical spaces constitutes our primary evidence, our approach engages the methods of material culture ${ }^{2}$ and material history, a methodology infrequently used in the history of science and medicine. ${ }^{3}$ In turn, in order to interpret the changes in operating room design, we situate them in the context of the history of surgery. The architecture of health care both illustrates and shapes the identity of patients and doctors, as well as their inter-relationship. It structures surgeons' activities and expresses their status as actors, as

(C) Annmarie Adams and Thomas Schlich 2006

*Annmarie Adams, PhD, Professor, School of Architecture, McGill University; Thomas Schlich, MD, Associate Professor, Department of Social Studies of Medicine, McGill University. Address for correspondence: Professor Annmarie Adams, School of Architecture, McGill University, 815 Sherbrooke St. West, Montreal, Quebec, Canada H3A 2K6;

e-mail: annmarie.adams@mcgill.ca

We are grateful to two anonymous reviewers, to David Theodore, whose skilful research and editing improved this paper, and to the John Bland Canadian Architecture Collection at McGill University, which holds many of the hospital's drawings. Annmarie Adams would also like to acknowledge the granting agencies: Canadian Institutes of Health Research, the Hannah Institute for the History of Medicine, and FCAR, for their support of historical research on the Royal Victoria Hospital. This paper is partially excerpted from Adams' book manuscript, Modernizing hospitals: Edward F. Stevens and the architecture of medicine, 1893-1943, currently under review. Thomas Schlich acknowledges the Canada Research Chair Program and the Canadian Institutes of Health Research for their support of his research on surgery. We presented an earlier version of this paper at the History of Science Society, held in Cambridge, Massachusetts, November 2003, and are appreciative of the feedback we received, especially from Gerard J Fitzgerald and Mary Anne Poutanen.

\begin{abstract}
${ }^{1}$ Scholars traditionally interpret the history of the operating room as part of the history of the modern hospital, e.g., Charles E Rosenberg, The care of strangers: the rise of America's hospital system, New York, Basic Books, 1987, or as part of the history of surgery in general, e.g., Owen $\mathrm{H}$ Wangensteen and Sarah D Wangensteen, The rise of surgery: from empiric craft to scientific discipline, Folkestone, William Dawson and Sons, 1978, pp. 453-73. For a separate history of the operating room, see Christoph Mörgeli, The surgeon's stage: a history of the operating room, Basel, Editiones Roche, 1999.

${ }^{2}$ On the pitfalls of interpreting the material culture of surgery in terms of function, see Ghislaine Lawrence, 'The ambiguous artifact: surgical instruments and the surgical past', in Christopher Lawrence (ed.), Medical theory, surgical practice: studies in the history of surgery, London and New York, Routledge, 1992, pp. 295-314, on pp. 298-300.

${ }^{3}$ Exceptions, that is scholarly work that does use material culture, would include: Dianne Dodd, 'Nurses' residences: using the built environment as evidence', Nursing History Review, 2001 9: 185-206; Annmarie Adams, 'Rooms of their own: the nurses' residences at Montreal's Royal Victoria Hospital', Material History Review, 1994, 40: 29-41; idem, 'Borrowed buildings: Canada's temporary hospitals during World War I', Can. Bull. Med. Hist., 1999, 16 (1): 25-48; Rosemary Gillespie, 'Architecture and power: a family planning clinic as a case study', Health \& Place, 2002, 8: 211-20; Charles R R Hayter, 'The clinic as laboratory: the case of radiation therapy, 1896-1920', Bull. Hist.
\end{abstract}




\section{Annmarie Adams and Thomas Schlich}

well as reinforcing specific scientific theories. ${ }^{4}$ Thus, spatial structures like operating rooms can be understood as material evidence of ongoing changes in the status and self-image of surgeons. ${ }^{5}$

Historians typically explain the changes in operating room design in the course of the nineteenth and twentieth centuries as physical necessities that simply accommodated the growing requirements of antisepsis and asepsis. ${ }^{6}$ What is overlooked in this approach is that spaces designed for surgery manifest a more general attitudinal change within surgery. Moreover, surgery has a special role in the development of the twentieth-century hospital. In the first decades of the twentieth century the field was central in moving the hospital "from the cultural periphery to become a core institution, crucial to developments in both medicine and science". This transformation required buildings that "evoked precision, technology, and the promise of a new science". 8 By the mid-twentieth century, the department of surgery was typically considered the "heart of the hospital", 9 with the operating room as its inner sanctum.

Our hypothesis is that by the post-Second World War period, spaces for science ${ }^{10}$ prevailed over earlier architectural references, such as the theatre and classroom, as a model for the operating room. Operating rooms abetted the significance of science on two related levels: firstly, surgeons, like laboratory scientists, pursued a strategy of control. Secondly, laboratory science also served as a paradigm of medical rationality central to the legitimization of the further expansion of surgeons' field of activity. The post-war enshrinement of the operating room as a space of experimental science can thus be understood within the framework of surgery's broad aspirations of becoming a science. $^{11}$

Med., 1998, 72: 663-88; and Peter Galison, Image and logic: a material culture of microphysics, University of Chicago Press, 1997.

${ }^{4}$ See Peter Galison, 'Buildings and the subject of science', in Peter Galison and Emily Thompson (eds), The architecture of science, Cambridge, MA, and London, MIT Press, 1999, pp. 1-25, on pp. 11-12.

${ }^{5}$ Other authors who have attempted similar analyses are Lindsay Prior, 'The architecture of the hospital: a study of spatial organization and medical knowledge', Br. J. Sociol., 1988, 39: 86-113. Prior interprets the spatial organizations in hospitals in relation to the discursive practices of which they form a part. J T H Connor, 'Bigger than a bread box: medical buildings as museum artifacts', Caduceus, 1993; 9: 119-30, and Thomas A Markus, Buildings and power: freedom and control in the origin of modern building types, London and New York, Routledge, 1993, also use hospital architecture as evidence of medical and social change.

${ }^{6} \mathrm{~J} \mathrm{~T} \mathrm{H}$ Connor, 'The Victorian revolution in surgery', Science, 2 Apr. 2004, 304: 54-5; Michael Essex-Lopresti, 'Operating theatre design', Lancet, 20 Mar. 1999, 353: 1007-10, p. 1007; Guenter B Risse, Mending bodies, saving souls: a history of hospitals, Oxford University Press, 1999, p. 387.
${ }^{7}$ Allan M Brandt and David C Sloane, 'Of beds and benches: building the modern American hospital', in Galison and Thompson (eds), op. cit., note 4 above, pp. 281-305, on p. 288.

${ }^{8}$ Ibid., p. 288.

9 'Le cœur de l'hôpital', Pierre-Yves Donzé, 'L'ombre de César : les chirurgiens et la construction du système hospitalier vaudois (1840-1960)', $\mathrm{PhD}$ thesis, University of Neuchatel, 2004, p. 111.

${ }^{10}$ On the significance of spaces for the production of scientific knowledge, see, for example, Galison, op. cit., note 4 above; Adi Ophir and Steven Shapin, 'The place of knowledge: a methodological survey', Science in Context, 1991, 4: 3-21.

${ }^{11}$ When discussing the influence of surgeons on the architecture of operating rooms, architect William A Pite characterizes his profession's role in this context as one of coordinating surgeons' and nurses' demands and "translating them into a consistent and logical arrangement". Pite reports that deep and prolonged discussions among surgeons about the requirements of surgical spaces often took place, "before the architect appears upon the scene'. William A Pite, 'Hospital operating theatres", The Architects' Journal, 24 June 1925, 61: 968-72, p. 968. 


\section{The Royal Victoria Hospital}

This adoption of the ideals of experimental science is discernable in the architecture for surgery. Facilities for animal experiments, for example, became part of the buildings designed for surgeons. In Montreal the new Pathology Building (Figure 1) at McGill University for the Royal Victoria Hospital in Montreal, designed by the noted Artsand-Crafts architect Percy Nobbs in 1922, and the adjacent Montreal Neurological Institute (Figure 2) as imagined by the neurosurgeon Wilder Penfield (1891-1976), illustrate the significance of experimentalism in architectural terms. A smaller, house-like structure accommodated the pathology institute's caretaker and housing for experimental animals, connected to the hospital by a romantic covered passageway. Penfield's famous drawing for the Neurological Institute, a perspectival elevation that specifies vertical adjacencies drawn on New York Biltmore hotel stationery, shows accommodation for animals on the top floor of the hospital.

In its overall arrangement, too, the Royal Victoria Hospital (Figure 3) is an ideal demonstration of the changes in the orientation of surgery over time. In the first half of the twentieth century it was one of the world's foremost teaching hospitals (among the first accredited by the American College of Surgeons in 1919), and home turf to surgical giants, the thoracic surgeon Norman Bethune (1890-1939), professor of surgery Edward William Archibald (1872-1945), Penfield and others. Its various architectural components were designed by world-class hospital architects, notably the British architect Henry Saxon Snell, the North Americans Stevens and Lee, and other non-specialists such as McKim, Mead and White and the Olmsted landscape firm. It therefore provides an excellent snapshot of avant-garde design. Secondly, there exists a plethora of architectural drawings of its surgical spaces. The drawings by Snell, for example, have only recently been found and have never been published (Snell's surgical building was demolished in 1953). As a case study, the Royal Victoria is thus at the same time unique and also representative of more general trends; it is local and universal, monumental and vernacular. And because its surgical spaces have been so well documented, it is a good opportunity to test the validity of using material evidence to assess our hypothesis.

\section{Surgery and Science}

Science has meant many different things in the course of medical history. ${ }^{12}$ Ever since the so-called laboratory revolution in medicine in the nineteenth-century, however, it was above all the laboratory-based experimental sciences that supplied an epistemic and practical alternative to the traditional medical logic of individual experience and judgement. According to the scientific approach, the basic laws governing the functions of a biological organism were also the basis of good medical practice. Consequently, the knowledge necessary for successful treatment was no longer expected to come from the bedside but rather from the laboratory. ${ }^{13}$

\footnotetext{
${ }^{12}$ John Harley Warner, 'The history of science and the sciences of medicine', Osiris, 1995, 10: 164-93.
}

\footnotetext{
${ }^{13}$ Andrew Cunningham and Perry Williams (eds), The laboratory revolution in medicine, Cambridge University Press, 1992.
} 


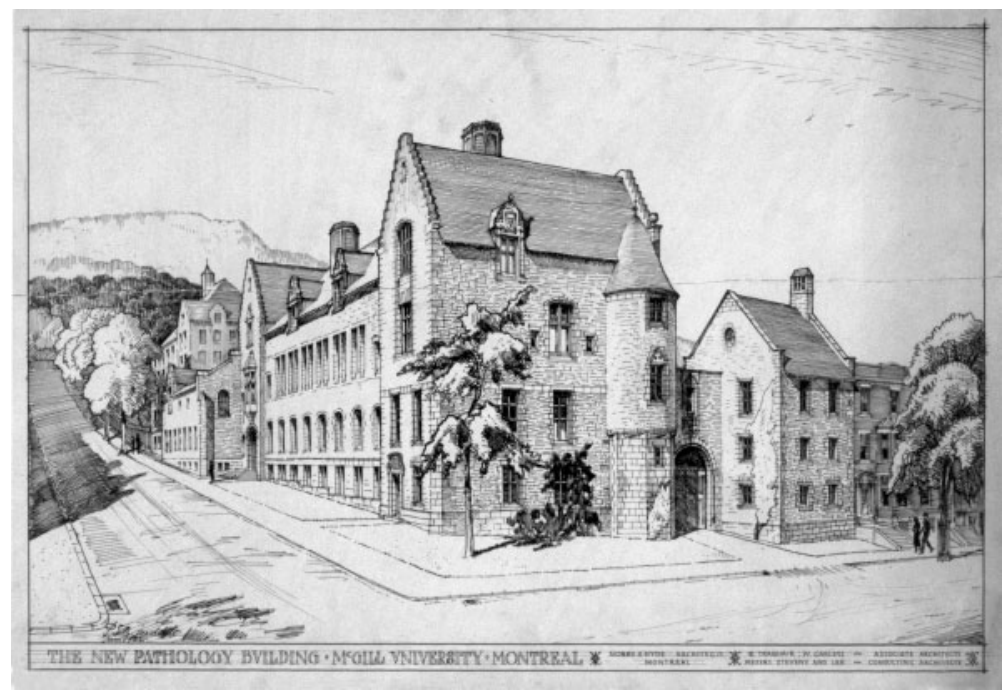

Figure 1: Perspective drawing by architect Percy Nobbs of the Pathology Building, McGill University, across University Street from the Royal Victoria Hospital. The smaller, gabled pavilion to the right of the main building, linked by an overhead bridge, was for the pathology institute's caretaker and experimental animals (John Bland Canadian Architecture Collection, McGill University).

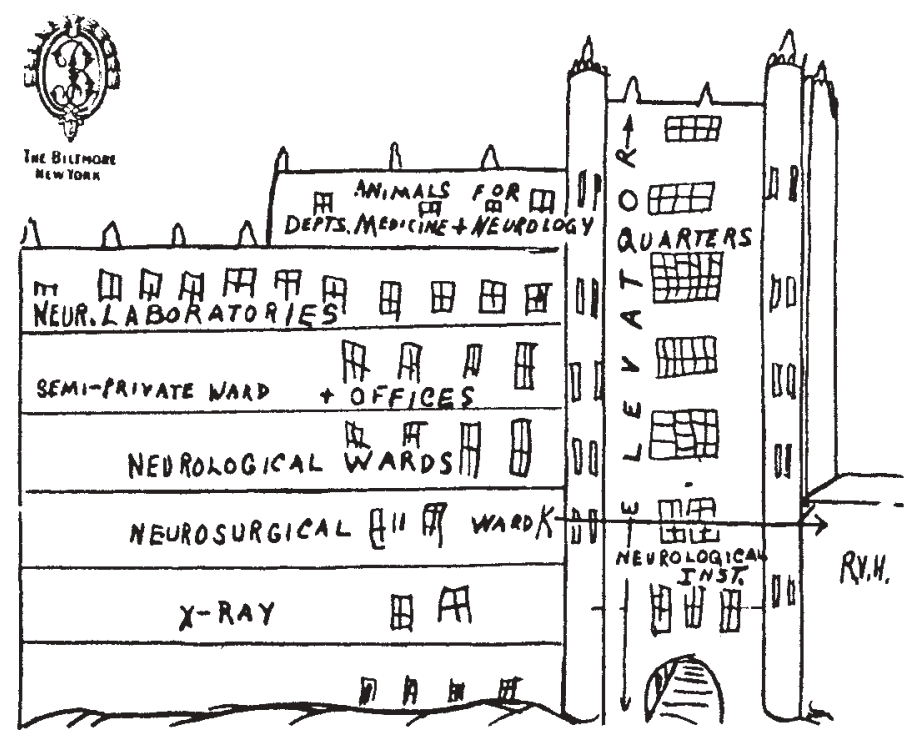

Figure 2: The neurosurgeon Wilder Penfield's famous drawing for the Neurological Institute, Montreal, drawn on New York Biltmore hotel stationery. Note the accommodation for animals on the top floor of the hospital (With permission of the Wilder Penfield Archive, Osler Library, McGill University). 


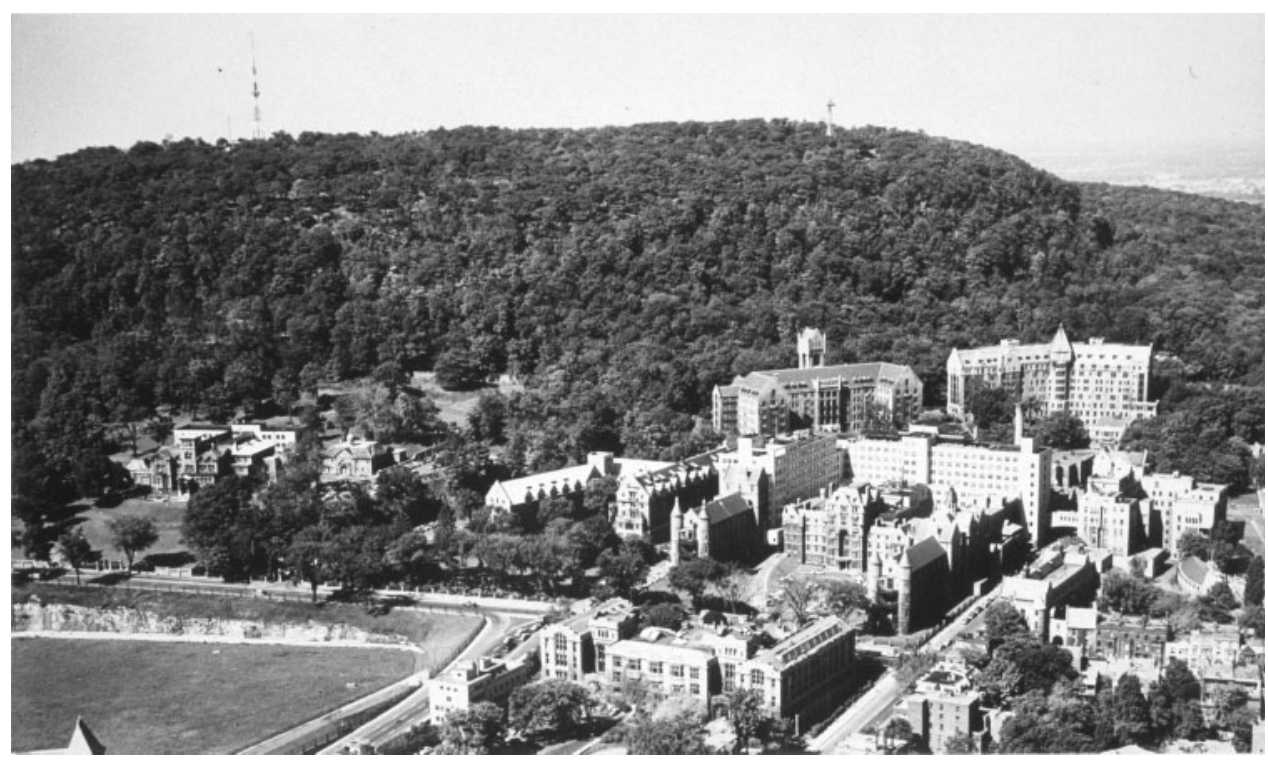

Figure 3: The Royal Victoria Hospital was built in phases over more than a century. This aerial photograph of the 1970s shows the main pavilion-plan hospital designed by Snell. The Ross Memorial Pavilion by Stevens and Lee is the building directly above it to the left, with the prominent square tower, framed by Mount Royal. The ten-storey, 375 feet long Surgical Wing of 1955 sits directly behind the agitated silhouette of Snell's hospital (Collection Royal Victoria Hospital).

Historically, the rise of surgery and the laboratory revolution in medicine occurred contemporaneously: during the same period when surgeons became leading and prestigious representatives of the medical profession, laboratory science became the ideological basis of medical knowledge and practice. As a result, by the late nineteenth century, the visible changes in both surgery and laboratory science were championed as the embodiment of progress in diagnosis and therapy. ${ }^{14}$ As the medical historian Joel Howell notes, new operations such as the tonsillectomy, the appendectomy and, in particular, the thyroidectomy were seen as based on science. ${ }^{15}$ Engaging a new scientific ethos, these innovative procedures helped surgeons project an image of themselves as bold, progressive, scientific reformers, rather than merely highly skilled technicians. In 1899 the noted British physician Sir John Burdon-Sanderson underlined this distinct status of surgery when he stated that "one of the most striking points of difference [between surgeons and physicians] is that the influence of scientific discovery has been much greater in surgery than in medicine". 16

\footnotetext{
${ }^{14}$ Warner, op. cit., note 12 above, p. 182.

${ }^{15}$ Joel D Howell, Technology in the hospital: transforming patient care in the early twentieth
}

century, Baltimore and London, Johns Hopkins University Press, 1995.

${ }^{16}$ Ibid., p. 61. 


\section{Annmarie Adams and Thomas Schlich}

Surgeons could and did use this recourse to experimental science to attain cultural authority, much like physicians used Latin in an earlier time period. ${ }^{17}$ Surgeons thus based their newly acquired status as much on the technical power of science, which was its ability to heal, as on its cultural power, which is the ability to provide plausible explanations within a particular cultural context. In a way, this cultural power even encompassed the technical power of science, since, in the words of the medical historians Steve Sturdy and Roger Cooter, "technical values ... must themselves be understood as a form of cultural value". ${ }^{18}$ Changes in the material culture of surgery, therefore, echo these practical-technical and the cultural-symbolic dimensions.

Surgical and experimental physiological practices also shared a similar approach to the body. This similarity can be explained in part by their common origins. Physiological practice, based to a large extent on animal experiments, "owed a heavy debt to surgery, for example: with boldness, technique, and localistic ways of seeing informed by surgical training, such experimental physiologists as Xavier Bichat, François Magendie, and Claude Bernard wrested knowledge from the organism by direct surgical interference with life processes". ${ }^{19}$ Methodologically, experimental physiology was based on deliberate, well-aimed surgical interventions in experimental animals. ${ }^{20}$ Bernard, the godfather of experimental physiology, emphasized the parallels between surgery and physiology in several passages of his canonical 1865 Introduction to experimental medicine. ${ }^{21}$ As late as 1909, the first surgeon Nobel Laureate Theodor Kocher claimed that physiologists had learned from surgeons how to perform their animal experiments in a useful way that brought the physiological action of the organs to light without distortion. ${ }^{22}$

Thus, the growing resemblance of operating rooms to laboratories registers the common aim of surgeons and scientists to control life processes. The ideal scientific laboratory is a place that creates conditions that allow the investigator to control life phenomena at will. ${ }^{23}$ Likewise, surgery is a "technology of control". The essence of surgery is to subject the

\footnotetext{
${ }^{17}$ Warner, op. cit., note 12 above, p. 178.

${ }^{18}$ Steve Sturdy and Roger Cooter, 'Science, scientific management, and the transformation of Britain c. 1870-1950', Hist. Sci., 1998, 36: 421-66, on p. 449. Cf. Howell, op. cit., note 15 above, p. 2 : "Rather than simply attributing change to the march of science, it is far more interesting for the historian and valuable for the policymaker to examine when and how the appeal to science derived its current power".

${ }^{19}$ Warner, op. cit., note 12 above, p. 186.

${ }^{20}$ Thomas Schlich, Die Erfindung der Organtransplantation: Erfolg und Scheitern des chirurgischen Organersatzes (1880-1930), Frankfurt am Main, Campus, 1998, p. 225; John E Lesch, Science and medicine in France: the emergence of experimental physiology, 1790-1855, Cambridge, MA, Harvard University Press, 1984, pp. 5-8, 12-14, 50-124, 199-218.

${ }^{21}$ Claude Bernard, An introduction to the study of experimental medicine, transl. Henry Copley Greene,
}

New York, Dover, 1957 (original French edition, 1865), e.g., pp. 101, 102.

${ }^{22}$ Emil Theodor Kocher, 'Concerning pathological manifestations in low-grade thyroid diseases', Nobel Lecture, December 11, 1909, in Nobel lectures: Physiology or Medicine, volume 1 1901-1921, published for the Nobel Foundation by Elsevier, Amsterdam, 1964, pp. 330-83, on p. 331.

${ }^{23}$ This is the programme of physiology and experimental medicine as outlined by Claude Bernard, in his influential Introduction to the study of experimental medicine, op. cit., note 21 above, pp. 55-6; see also John V Pickstone, 'Ways of knowing: towards a historical sociology of science, technology and medicine', Br. J. Hist. Sci., 1993, 26: 433-58, see p. 437; and Bruno Latour, 'Give me a laboratory and I will raise the world', in K D Knorr-Cetina and M Mulkay (eds), Science observed, Beverly Hills, Sage 1983, pp. 141-70. 
living material of the patient's body to the surgeon's will. ${ }^{24}$ In order to achieve the necessary degree of control, both scientists and surgeons need highly specialized, purpose-built spaces. Both derive their special powers from the settings in which they work. Bruno Latour puts it bluntly, "the only place where they [laboratory scientists] are able and good workers is in their laboratories". ${ }^{25}$ Likewise surgeons are also able and good workers only in their operating rooms. In that special architecture the patient's body is rearranged, controlled, and made visible in ways that make it possible to master and manipulate it. Achieving control, however, not only means controlling the patient's body-like preventing haemorrhage or fixing a body part's shape and behaviour-it also means controlling the surgical environment.

The increase of control by design can be traced in the three types (Figure 4) of surgical arrangements at the Royal Victoria Hospital, especially with regards to access, scale, illumination and ventilation. These types roughly correspond to the Victorian operating theatre, the interwar surgical suite, and the post-war operating room (or "OR"). Note the changing architectural language for these spaces: theatre, suite, and then room, further evidence of changes in scale and function.

\section{Spaces for Surgery:}

\section{Type I: The Operating Theatre}

The original design for the pavilion plan Royal Victoria illustrates our Type I. ${ }^{26}$ Snell produced drawings for both a medical theatre, to be constructed behind the east wards, and a surgical theatre, for the west (surgical) wards (Figures 5-8). Both medical and surgical theatres were rectangular structures, with steep gabled roofs, connected to the hospital by a narrower corridor. The main level comprised semi-circular, tiered seating, positioned to view procedures which took place along the long elevation of the building. As drawn in February 1892, the theatre was roughly 53 feet by 44 feet, and was minimally connected to its (west) ward tower, and support rooms, for anaesthesia and instruments, by a small corridor (level with the floor of the theatre) with four windows. The surgical theatre was thus designed as a semi-public space with all the constituents of a real, non-medical theatre complex: on the ground floor, beneath the theatre seats, was a room for students' "hats \& cloaks", and an adjacent washroom (eight urinals, two toilets). ${ }^{27}$ Medical students were intended to enter the theatre directly from the exterior (north-east corner), through a small lobby.

\footnotetext{
${ }^{24}$ See, for example, Thomas Schlich, Surgery, science and industry: a revolution in fracture care, 1950s-1990s, Basingstoke, Palgrave Macmillan 2002, p. 240; control is a dominant theme in surgical literature, such as control of infection, control of haemorrhage, etc., see, for example, Martin Kirschner, Operative surgery: general and special considerations, transl. I S Ravdin, Philadelphia and London, J B Lippincott, 1931, pp. 229-349.

${ }^{25}$ Latour, op. cit., note 23 above, p. 163.
}

\footnotetext{
${ }^{26}$ On pavilion plan hospitals, see Jeremy Taylor, The architect and the pavilion hospital: dialogue and design creativity in England 1850-1914, London, Leicester University Press, 1997.

${ }^{27}$ On the elevation drawing No. 13, labelled HJK, this washroom section is $\mathrm{X}$-ed out in pencil, and someone has written "out", perhaps indicating that these facilities were not included in the hospital as built.
} 


\section{Annmarie Adams and Thomas Schlich}

Spaces for Surgery

\begin{tabular}{|c|c|c|c|}
\hline & Type I & Type II & Type III \\
\hline Spatial model & Theatre & Classroom & Laboratory \\
\hline $\begin{array}{l}\text { Royal Victoria Hopital } \\
\text { case study }\end{array}$ & $\begin{array}{l}\text { Original building, West } \\
\text { Wing } 1893\end{array}$ & $\begin{array}{l}\text { Ross Memorial } \\
\text { Pavilion } 1916\end{array}$ & Surgical Pavilion 1955 \\
\hline Architect & H Saxon Snell, Britain & $\begin{array}{l}\text { Stevens \& Lee, Boston } \\
\text { and Toronto }\end{array}$ & $\begin{array}{l}\text { Barott, Marshall, } \\
\text { Montgomery \& } \\
\text { Merrett, Montreal }\end{array}$ \\
\hline No. of operating rooms & 1 & 2 & 12 \\
\hline Size of each room & 53 feet by 44 feet & 20 feet by 30 feet & 20 feet by 20 feet \\
\hline No. of observers & $200-250$ observers & - & $\begin{array}{l}2 \text { rooms with } \\
\text { observation galleries; } \\
5 \text { observers per gallery }\end{array}$ \\
\hline Lighting & $\begin{array}{l}\text { Natural light through } \\
\text { roof and wall }\end{array}$ & $\begin{array}{l}\text { Natural light through } \\
\text { wall, artificial lighting }\end{array}$ & Artificial lighting only \\
\hline Access and links & $\begin{array}{l}\text { Separate pavilion, door } \\
\text { and window to exterior }\end{array}$ & $\begin{array}{l}\text { Embedded in suite of } \\
\text { rooms, window to } \\
\text { exterior }\end{array}$ & $\begin{array}{l}\text { Exclusive, controlled } \\
\text { access, no link to } \\
\text { exterior }\end{array}$ \\
\hline
\end{tabular}

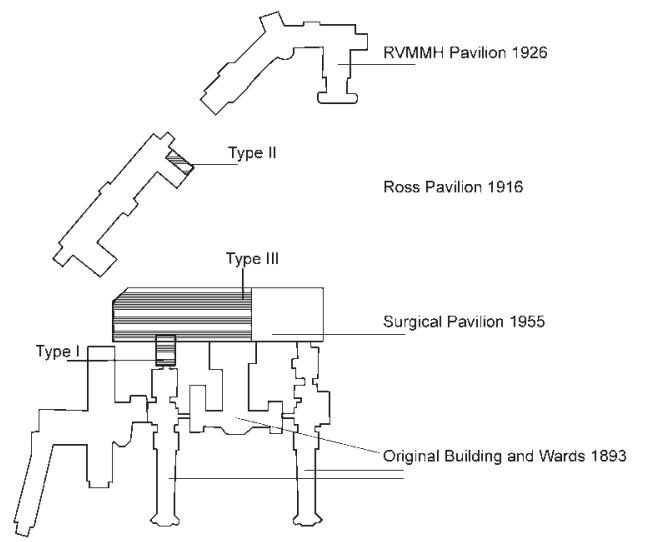

Royal Victoria Hospital, Montreal. Site plan of principal buildings, 1893-1955

Figure 4: This matrix summarizes our three types of surgical spaces and their locations at the RVH (drawn by David Theodore).

The larger scale (undated) plan (Figure 6), a remarkable drawing which shows both levels of the theatre simultaneously, is accompanied by a splendid detail of the students' seats. The distance between the cast iron standards which differentiated each level of seat was two feet; each standard was three feet high. The rhythm of change-seat, step, seat was beautifully paced at one foot. The theatre could accommodate 200 or 250 students. $^{28}$

${ }^{28}$ See 'The Royal Victoria Hospital', Montreal Med. J., Jan. 1894, 22 (7): 534-53, on p. 539, the hospital secretary John J Robson describes accommodation for 300 students. 


\section{Surgery at the Royal Victoria Hospital, Montreal, 1893-1956}

The most interesting architectural feature of the surgical and medical theatres at the Royal Victoria was the strategy to provide natural illumination. ${ }^{29}$ At the time, natural light was seen as most appropriate for surgical purposes. Just over 24 feet above the theatre floor, a glass gable popped up from the main section of the slate roof and presumably flooded the space with natural light, augmented by a huge window in the north-east wall, behind the surgeon. A series of hinged panels (called "ceiling lights" in the drawing) made it possible to close off the lantern. A large-scale (five feet $=1$ inch) section by Snell shows both the framing of this generous lantern, and its elevation. Small windows ring the entire lantern (eight on the long side; five on the short side), just below the copper roof. Two small ventilators also punctuated Snell's roof, presumably flushing the theatre with fresh air.

These plans represent the larger surgical amphitheatre type of operating room commonplace in metropolitan centres in Europe and North America in the late nineteenth century. This period, as the historians of surgery Owen Wangensteen and Sarah Wangensteen noted, "marked the summit of the surgeon's dazzling actor-role". 30 Towards the end of the century elegant new operating theatres appeared that mirrored the heightened public interest and confidence in surgery. ${ }^{31}$

Surgery converged even more with experimental science when, in the late nineteenth and early twentieth centuries, surgeons tried to make their field more scientific. Like laboratory scientists, surgeons reframed their work in terms of the replicability of results. On a general level, scientific medicine, as formulated by Bernard, tries to make real world phenomena as controllable and predictable as laboratory phenomena. Bernard's approach was the most influential attempt in modern times to give medical practice a rational basis by transforming it from an art into a science. First he attempted to gain complete control of the workings of the organism in the laboratory; he then transferred this control to the clinical setting. "Experimental medicine", as it was called, would prove appealing to generations of doctors after Bernard. ${ }^{32}$ For the field of surgery this meant that surgeons, like laboratory investigators, could replicate results by respecting biological laws, and ensuring predictability and control. ${ }^{33}$ In the laboratory, observations become stable, and thus real, if they can be replicated. Similarly, a surgical technique becomes viable on a general level once it can be successfully repeated by different surgeons on different patients. $^{34}$

\footnotetext{
${ }^{29}$ Changes in hospital lighting took place against a whole host of associated changes, not the least being the advent and widespread use of electricity. Although the original Royal Victoria Hospital was wired for electricity, its use was interrupted daily at 11:00 pm. Improvements were made in 1899 with the construction of a new laundry and boiler building. See D Sclater Lewis, Royal Victoria Hospital 1887-1947, Montreal, McGill University Press, 1969, pp. 129-30.

${ }^{30}$ Wangensteen and Wangensteen, op. cit., note 1 above, p. 462.

${ }^{31}$ Ibid., p. 464.

${ }^{32}$ Bernard, op. cit., note 21 above; Schlich, Erfindung, op. cit., note 20 above, pp. 222-40. It is
}

important to note that "experimental" does not refer here to the open-endedness of the outcome, as when it is said that a treatment has not yet become routine but is still "experimental". On the contrary, "experimental medicine" in Bernard's sense denotes complete control and predictability of treatment results.

${ }^{33}$ Schlich, Surgery, op. cit., note 24 above, pp. 106-7; Bernard, op. cit., note 21 above.

${ }^{34}$ The variation in individual skill is an ongoing issue in surgery. Even if a procedure can be shown to be viable in the hands of an individual master surgeon, the challenge remains to institute it on a larger scale; see Schlich, Surgery, op. cit., note 24 above, pp. 65-85. 


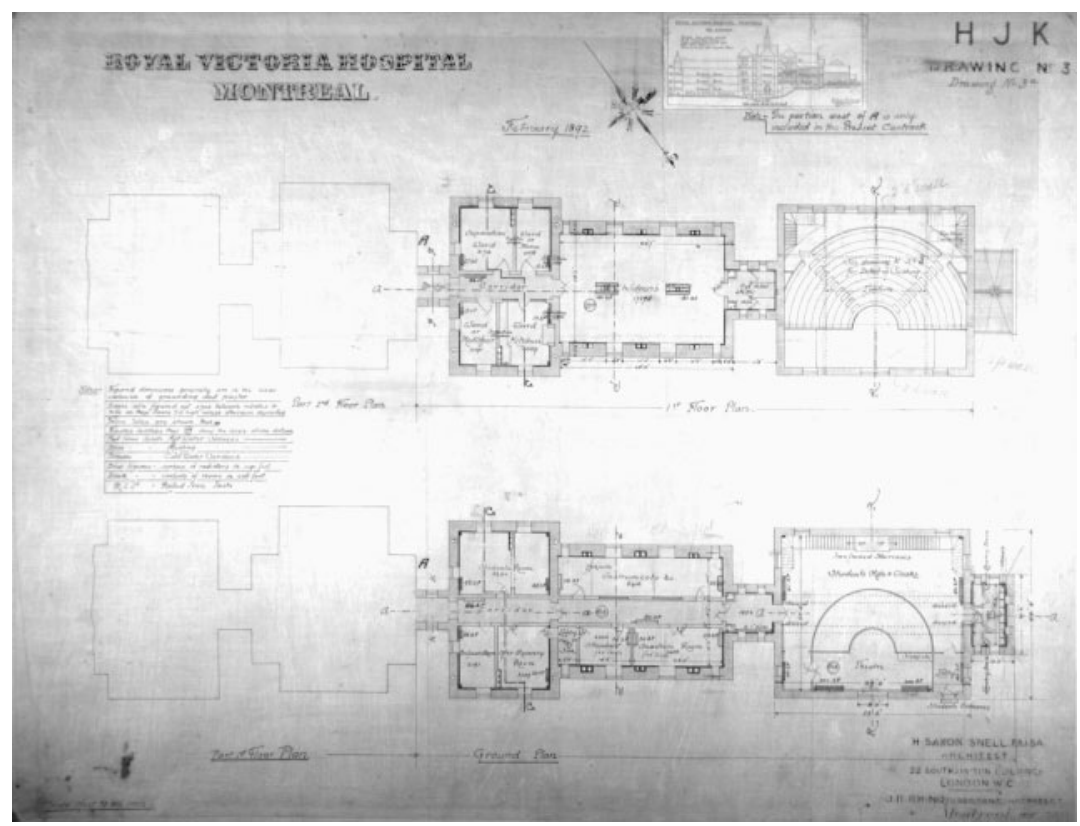

Figure 5.

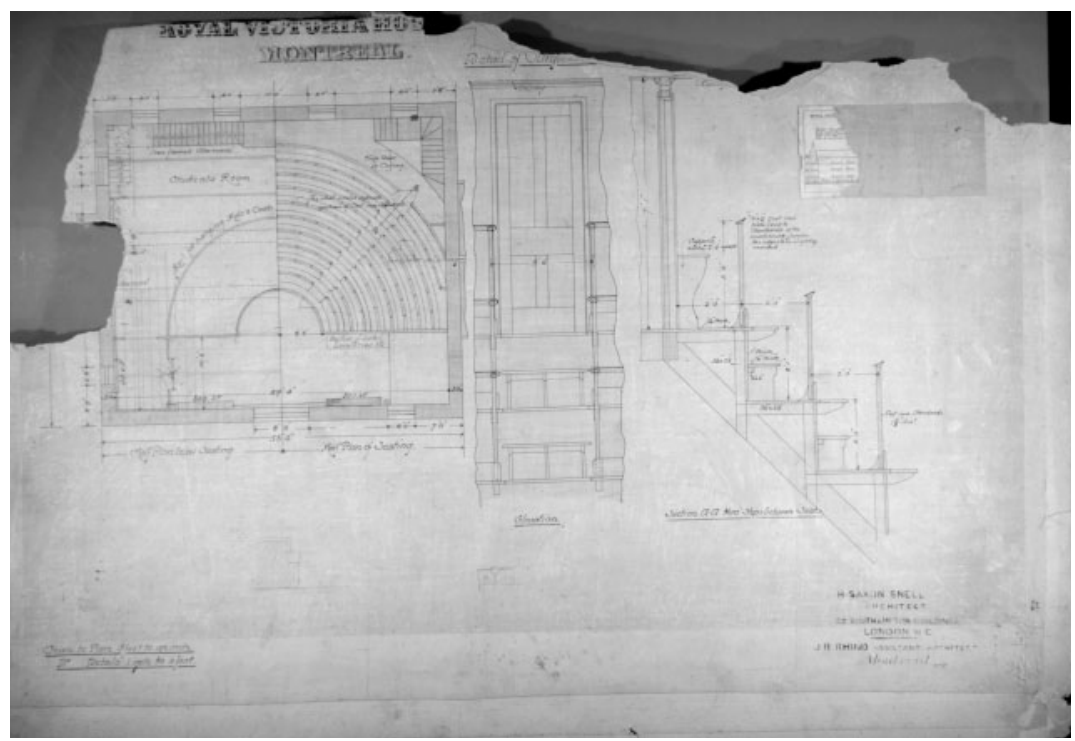

Figure 6. These plans, sections, and elevations of the surgical theatre at the Royal Victoria Hospital by Henry Saxon Snell have been recently uncovered and preserved. They illustrate our Type I surgical space: large, accessible from the exterior, naturally lit and ventilated (John Bland Canadian Architecture Collection, McGill University). 


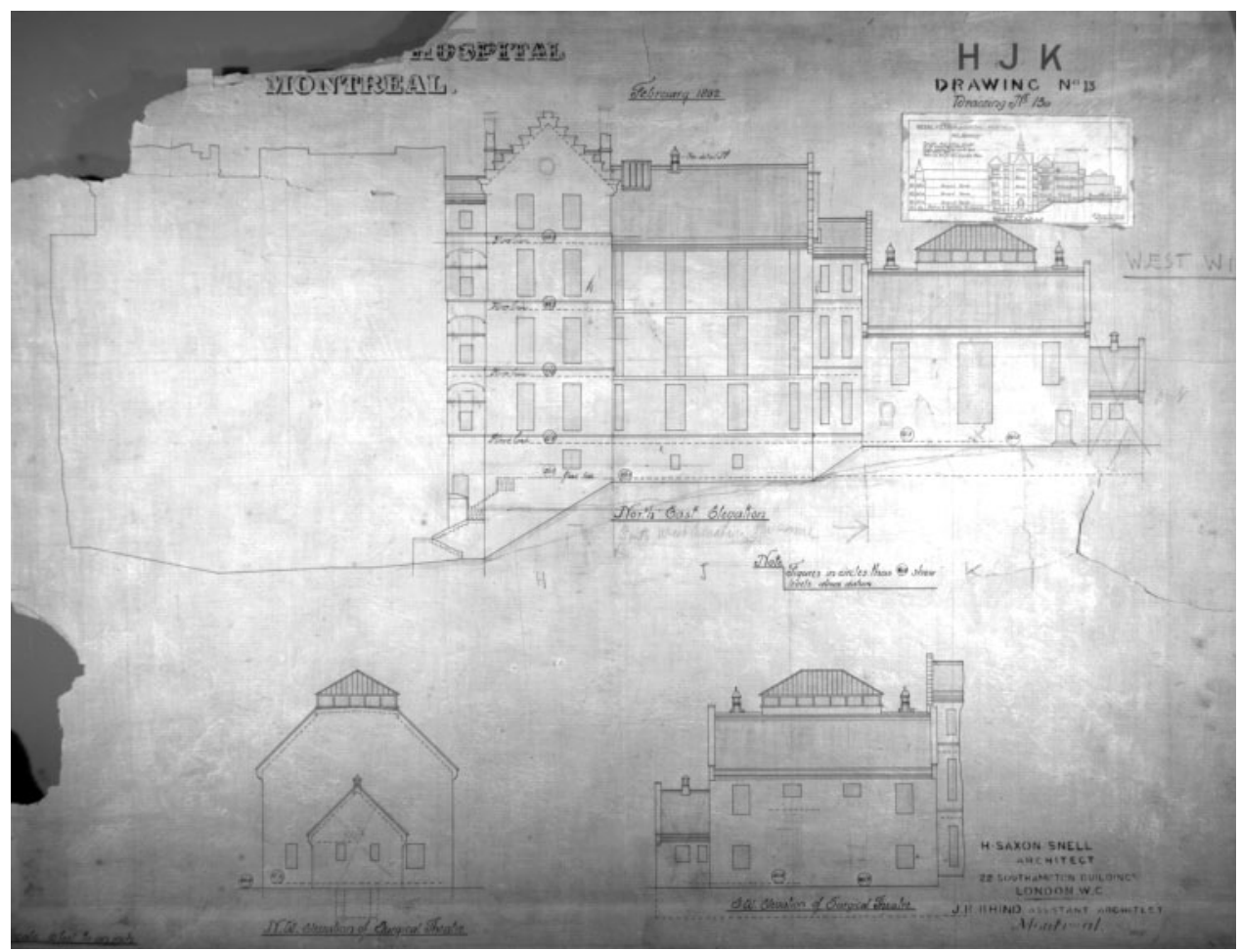

Figure 7.

One of the most legible steps in surgery's emulation of laboratory science is the emergence of a new type, physiological surgery, in the late nineteenth century. Whereas surgeons had previously been interested primarily in anatomical structures, and surgical innovation had been focused on new ways of removing diseased body structures, a new generation of surgeons began to reconstruct the functions of internal organs. The paradigmatic technology of this switch in perspective was organ transplantation, which emerged from this confluence of surgery and laboratory science between 1880 and $1920 .{ }^{35}$ With transplant surgery, surgeons turned away from a purely local and structural approach, took up experimental research methods, and started to look at the body from a systemic and functional point of view. Experimental physiology replaced pathological anatomy as a reference science. The experimental approach went beyond observation and description of life phenomena, favouring active intervention into the living organism as a way of controlling body functions.

\footnotetext{
${ }^{35}$ The importance of transplant surgery was by no means just symbolic. In this period, hundreds of organ transplants were performed on patients. Mainstream surgeons remained convinced of the immediate
}

viability of organ transplantation up until about the First World War; see Schlich, Erfindung, op. cit., note 20 above. 


\section{Annmarie Adams and Thomas Schlich}

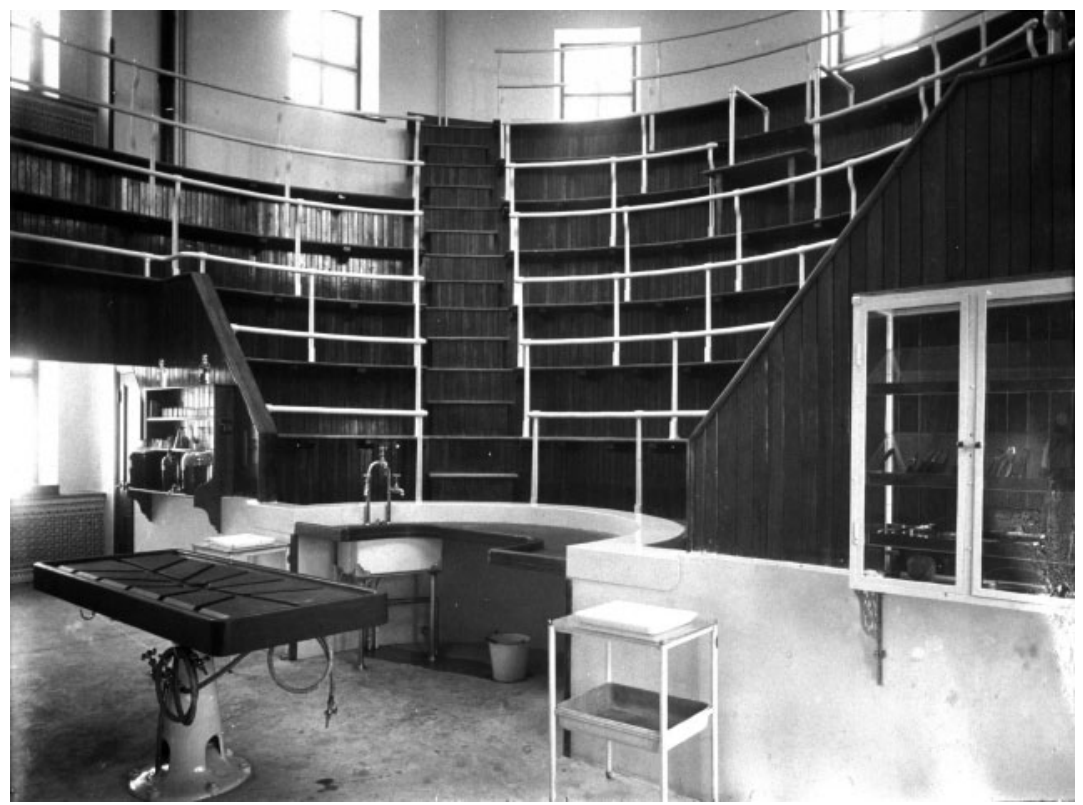

Figure 8. Surgical theatre, Royal Victoria Hospital, Montreal, QC, about 1894, photograph by William Notman \& Son. (View 2735, Notman Photographic Archives, McCord Museum of Canadian History, Montreal.)

Partaking in experimentalism's cultural prestige, academic surgery was among the medical disciplines that adopted the ideal of experimental physiology and established itself as a scientific research discipline at universities. Innovative surgeons turned to the laboratory sciences of physiology and bacteriology. Like other clinicians, surgeons performed laboratory experiments in order to compete with other disciplines in university medicine. $^{36}$

Within one generation, then, the old non-experimental approach to surgery had become irrational: experimentation now seemed to be "the only true method of inquiry", as the British surgeon Victor Horsley remarked in 1892. Horsley, who himself alternated between physiology and surgery, found it obvious that one cannot explain organ function from structural details, and he was puzzled how his predecessors could have published so much about the thyroid gland without ever checking their hypothesis by a simple experiment. ${ }^{37}$

${ }^{36}$ Ibid., pp. 226-30. Ulrich Tröhler, 'Surgery (modern)', in W F Bynum and Roy Porter (eds), Companion encyclopedia of the history of medicine, 2 vols, London and New York, Routledge, 1993, vol. 2, pp. 984-1028; Thomas Schlich, 'The emergence of modern surgery', in Deborah Brunton (ed.), Medicine transformed: health, disease and society in Europe, 1800-1939, Manchester University Press, 2004, pp. 61-91.

\footnotetext{
${ }^{37}$ Victor Horsley, 'Remarks on the function of the thyroid gland: a critical and historical review', Br. med. $J ., 1892$, i: 215-19, 265-8, see p. 216. Horsley did thyroid ablation experiments on apes to explore the role of the organ in a "scientific way". In 1885 Horsley was the first investigator who could offer a really convincing animal model of a lack thyroid function, Schlich, Erfindung, op. cit., note 20 above, pp. 58, 61-2.
} 


\section{Type II: The Operating Suite}

At a time when the practice of surgery was seen as a particularly "scientific" feature of hospitals, the transformation of the old-fashioned operating theatre into the operating suite marked the rise of surgery. ${ }^{38}$ The interwar suite as a surgical space is very different from the Victorian theatre: now the operating room is embedded in the building, though always at one end or on top. In this second type of surgical arrangement the room for surgery is part of a suite of smaller spaces. The American architect and noted hospital specialist Edward F Stevens called his surgical department (Figure 9) at the RVH's Ross Memorial Pavilion "the most complete". ${ }^{39}$ Located on the fifth floor, in the north end of the building, it included two large operating rooms, as well as surgeons' sitting rooms, two anaesthetic rooms, and work rooms. There are no spectators, and it is insulated by smaller rooms-and certainly it has no direct entry from the exterior.

The emergence of these clearly separated but spacious, lavishly designed operating rooms indicates another step towards the systematic implementation of principles of control. ${ }^{40}$ Surgeons at the time emphasized this need for isolation in order to protect the surgical rooms from the "dirt and noises" of the exterior, but also to shield the wards, private rooms and even the garden from sounds originating in the surgical suite. ${ }^{41}$ The architect William Pite wrote in 1925 that the operating rooms should be "situated where privacy and complete quiet can be secured ... If circumstances permit, the operating 'unit' should be isolated from the main building and cut off from the main corridor by a bridge approach". ${ }^{42}$ In the same period, experts such as the leading German surgeon Martin Kirschner pressed for exclusivity: "In the operating room we attempt to get along with as few persons as possible, not only for economy's sake, but also because the fewer workers the more quiet it is and the less danger there is of a slip in technic". ${ }^{43}$ In her 1914 article in the journal Modern Hospital, R K Felter, the nurse in charge of the operating room of the Royal Victoria Hospital, emphasized the importance of order, discipline and control. Warning against "confusion in the operating room", she claimed that "there should be no unnecessary talking and each movement should be executed quickly and noiselessly, and without coming in contact with other persons". 44

A greater number of small rooms not only afforded more control, it also provided for more efficiency. More rooms made it possible, as Kirschner stated in 1931, "to operate upon each case in a freshly prepared room without the loss of time". ${ }^{45}$ This was a time when surgeons did more and more operations within the hospital walls, so that "the increasing volume of surgical patients who passed through the operating rooms demanded new techniques for dealing with a new tempo and intensity of hospital care" ${ }^{46}$ The design concepts that answered to the speed with which surgeons worked in the surgical suite were

\footnotetext{
${ }^{38}$ Annmarie Adams, 'Modernism and medicine: the hospitals of Stevens and Lee, 1916-1932', J. Soc. Archit. Hist., 1999, 58: 42-61, on p. 42.

${ }^{39}$ Edward F Stevens, The American hospital of the twentieth century, 2nd rev. ed., New York, F W Dodge Corporation, 1928, p. 102.

${ }^{40}$ Mörgeli, op. cit., note 1 above, p. 234.

${ }^{41}$ Kirschner, op. cit., note 24 above, p. 250.
}

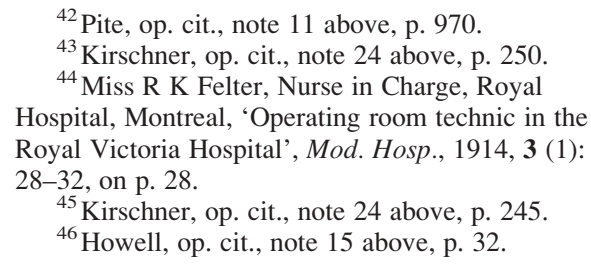

${ }^{42}$ Pite, op. cit., note 11 above, p. 970.

${ }^{43}$ Kirschner, op. cit., note 24 above, p. 250.

${ }^{44}$ Miss R K Felter, Nurse in Charge, Royal Hospital, Montreal, 'Operating room technic in the Royal Victoria Hospital', Mod. Hosp., 1914, 3 (1): 28-32, on p. 28.

${ }^{45}$ Kirschner, op. cit., note 24 above, p. 245.

${ }^{46}$ Howell, op. cit., note 15 above, p. 32. 


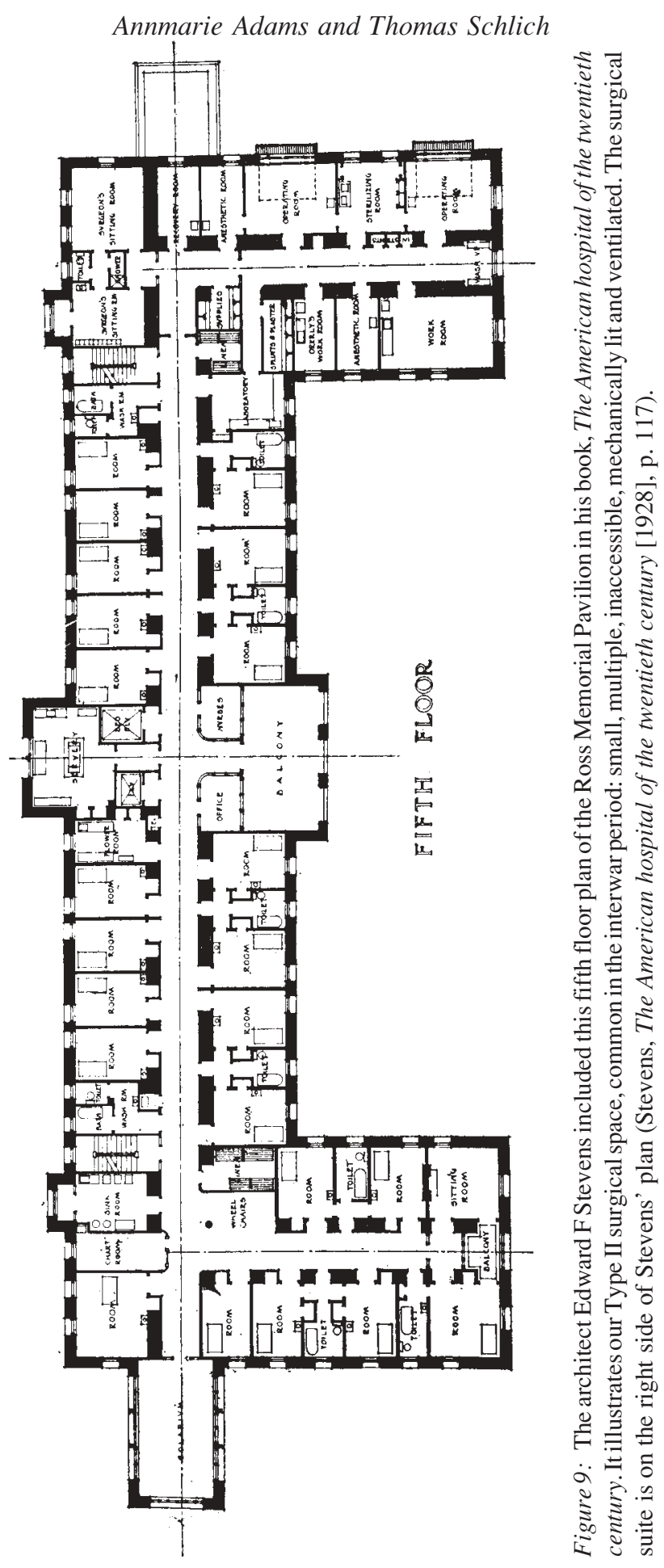

316 


\section{Surgery at the Royal Victoria Hospital, Montreal, 1893-1956}

likened to the assembly line employed in the car industry at the same time. ${ }^{47}$ The change in architecture also paralleled a change in the social organization of surgery: whereas the old surgical amphitheatre had embodied the hierarchy and a vertical division of labour, with the master of general surgery at the top as the centre of attention, the surgical suite recognized a more egalitarian, horizontally organized division of labour among members of the surgical team. The existence of a series of operating rooms, for example, meant that the head surgeon could no longer directly control every aspect of his department. His job was now to organize and distribute tasks among an increasing number of team members. ${ }^{48}$

At the same time, technical control of the surgical environment became even more important. In his textbook, Kirschner emphasized that major operations needed to be "undertaken in specially equipped rooms, in which not only the most minute asepsis is guaranteed, but the illumination, temperature, ventilation, and equipment have been considered". ${ }^{49}$ Surgeons themselves linked the predictability of surgical results with the degree of control over the environment. If surgeons controlled all the conditions under which they worked, Kirschner wrote, they could actually "predict the outcome with a certain degree of probability. This justifiable sense of security in the ultimate outcome of our surgical procedures is the result of the technical observance of the recognized laws of modern surgery". 50

Since ideally the control of life phenomena achieved in the laboratory was to be passed on to the doctor at the bedside or in the operating theatre as a means of controlling disease, it is not surprising that the certainty of success of the new therapy was often explicitly compared to the replicability of a physiological experiment. In 1909 Kocher made that comparison when he demanded "a physiological therapy" that would "produce real cures". 51

The boundaries between laboratory science and surgery soon became blurred: Surgeons inspired physiologists to perform their experiments, physiologists suggested operations to surgeons, experiments served as justification for operations and vice versa. Often surgeons worked as physiologists too. ${ }^{52}$ Many surgeons routinely performed the same operations on animals and on human patients for either research or therapy and switched effortlessly from the laboratory to the operating room and back. ${ }^{53}$ Over the course of time, even surgical fields like fracture care that had been relatively resistant to the rhetoric of experimental science — because of their overwhelmingly practical orientationexhibited a need for a basis in science. Cooter has identified the late 1950s as the main period when orthopaedics started to "take on the hues of science" and orthopaedic

\footnotetext{
${ }^{47}$ Donzé, op. cit., note 9 above, p. 113.

${ }^{48}$ Ibid., p. 111. New techniques of organization may well have made it theoretically possible for a single dominant surgeon to control more than one operating room. But this would have been a different kind of control from the direct supervision that had been the norm in Type I, the earlier, undivided operating theatres. On the growth of managerial capitalism in the twentieth century, see Alfred D Chandler, The visible hand: the managerial revolution in American business, Cambridge, MA, Belknap Press, 1977.
}

\footnotetext{
${ }^{49}$ Kirschner, op. cit., note 24 above, pp. 243-4. On the isolation of the OR from its environment, see Stefan Hirschauer, 'The manufacture of bodies in surgery', Soc. Stud. Sci., 1991, 21: 279-319, on pp. $283-4$.

${ }^{50}$ Kirschner, op. cit., note 24 above, p. 1 .

${ }^{51}$ Kocher, op. cit., note 22 above, p. 335.

${ }^{52}$ Schlich, Erfindung, op. cit., note 20 above, pp. $75-80$.

${ }^{53}$ Ibid., pp. 226-36. See, for example, Anton von Eiselsberg, 'Zur Frage der dauernden Einheilung verpflanzter Schilddrüsen und Nebenschilddrüsen',
} 

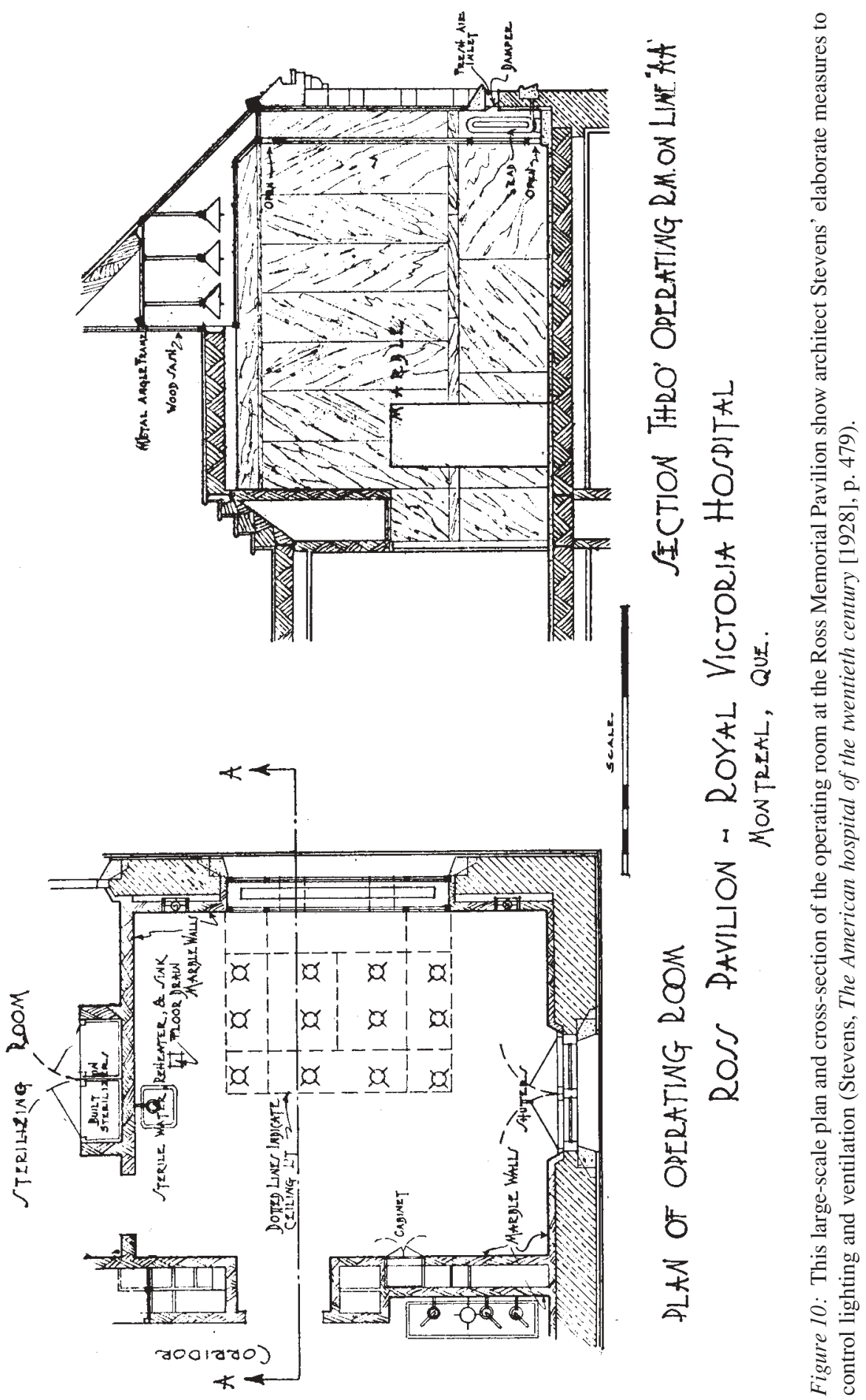
surgeons to invest increasingly in basic research. By adopting a new image based on the authority of science, they sought to present anatomical and physiological knowledge as the basis of good orthopaedic practice. In 1940 only 15 per cent of the papers published in the Journal of Bone and Joint Surgery were concerned with "investigative research", whereas in 1959 the number was closer to 50 per cent. ${ }^{54}$ By the second half of the twentieth century, then, laboratory science and its mandates of control and replicability had become ubiquitous in surgery. 55

The response to arrangements like the Ross surgical suite provides a striking material example of this surgical logic of control. It shows how surgeons preferred a maximum control of their working environment over the architect's vision of an aesthetic environment and thus underlines our argument. When Stevens designed the Ross surgical suite he was steadfast in his preference for natural light and was particularly proud of the illumination and ventilation: "entirely indirect, no lighting fixture being in the operating room, but all concealed behind the glazed ceiling" ${ }^{56} \mathrm{He}$ purposely sandwiched the radiators in the operating room between the outside window and a glass wall, open at the top, allowing both light and heated, fresh air to enter the room. The large-scale section of the Ross arrangement (Figure 10) was included in Stevens' classic book, The American hospital of the twentieth century. It shows his signature combination of large, north-facing vertical window and angled skylight. ${ }^{57}$ This flood of natural light was complemented by a grid of a dozen light fixtures suspended above glass next to the north wall.

Stevens' position on natural lighting was controversial and was particularly unpopular with surgeons. In nearly all the hospitals he designed across North America from 1912 to 1933, he specified windows in surgical suites and the surgeons subsequently boarded them up. This is further material evidence of their lust for more control. The surgeons preferred artificial lighting because it was easier to regulate physical qualities such as the light's quantity, colour, cleanliness, intensity, direction. ${ }^{58}$ In 1930 an article in the journal Canadian Hospital stated that, because it allowed "changes in intensity and quality", surgeons were "gradually realizing", that daylight was "unsuited for the requirements of the operating room", so that "some of the recently constructed hospitals have been built with daylight purposely excluded from the operating rooms, and in its stead, artificial illumination is installed". 59

Verhandlungen der Deutschen Gesellschaft für Chirurgie, 1914, 43: 655-69, on p. 656, who said that surgeons had performed transplants on humans in analogy to the animal experiments. On the close relationships and overlapping research of surgeons and physiologists, see, in more detail, Schlich, Erfindung, op. cit., note 20 above, pp. 91-198, 233-4.

${ }^{54}$ Roger Cooter, Surgery and society in peace and war: orthopaedics and the organization of modern medicine, Basingstoke, Macmillan, 1993, pp. 234-7. See also Schlich, Surgery, op. cit., note 24 above, pp. 86-109.

${ }^{55}$ For the second half of the twentieth century, see, for example, Robert Danis, Technique de l'ostéosynthèse, Paris, Masson, 1949, pp. 5-6; Martin Allgöwer, 'Wesen und Arbeitsgebiete des
Laboratoriums im Forschungsinstitut Davos', Helvetica Chirurgica Acta, 1962, 29: 176-9, on p. 178; Maurice Müller, 'Treatment of nonunions by compression', Clin. Orthop. Relat. Res., 1965, 43: 83-92, on p. 90; and Schlich, Surgery, op. cit., note 24 above, pp. 86-109.

${ }^{56}$ Stevens, op. cit., note 39 above, p. 102.

${ }^{57}$ Stevens used this window and skylight arrangement in the Bridgeport Hospital, Bridgeport, Connecticut, and the Barre City Hospital, Barre, Vermont, both illustrated in his book.

${ }^{58}$ This has also been pointed out by Howell, op. cit., note 15 above, pp. 58-9.

59 'Natural daylight not suited to operating room requirements', Canadian Hospital, Feb. 1930, 7 (2): $36-7$, on p. 36. On electrical improvements to the 


\section{Annmarie Adams and Thomas Schlich}

It is important to note that lighting is linked to dexterity in the architectural magazines, and the surgical table is described as the sum of the institution's and the surgeon's effectiveness: "The apex of hospital service is on the operating table. Here the entire organization of the hospital focuses on one vital, crucial spot-and often human life balances on the knowledge, skill and speed of the surgeon". Control of the surgeon's working environment is the first priority because "with human life at stake on every operating table in every hospital in the country, the best working conditions possible for operating surgeons are imperative", 60

\section{Type III: The Operating Room}

In the modern hospital, then, control of the surgical environment had reached a new order of magnitude. With this increasing sense of control, operating rooms became like laboratories. The well-documented influence of asepsis on operating room design in the late nineteenth ${ }^{61}$ and early twentieth centuries can be interpreted as the transformation of the surgical theatre into a special type of bacteriological laboratory. The designers of operating rooms subjected the spaces to the same precautions that governed a laboratory for bacterial research, intended to control microscopic life forms, especially to keep bacteria out of particularly vulnerable places. In the case of the laboratory, this was the pure culture of bacteria. In the space for surgery, however, it was the surgical wound. Louis Pasteur made this parallel between laboratory and operating room explicit: if he were a surgeon, he wrote, he would not only use thoroughly cleaned instruments, "but after having cleaned my hands with the greatest of care, I would subject them to rapid flaming". This was exactly what Pasteur did in his laboratory with all objects that came into contact with his microbial cultures in order to avoid contamination. He continued that he "would use only lint, bandages and sponges previously exposed to air temperatures of 130 to $150^{\circ} \mathrm{C}$ and use water that had been heated to temperatures of 110 to $120^{\circ} \mathrm{C} "{ }^{\prime 2}$ Pasteur here tells surgeons how to achieve control of their environments matching his control in his laboratory. In so doing, Pasteur the scientist points out how the principles used in laboratories as spaces for control could be used in operating rooms by a simple change of scale. The power of controlling micro-organisms achieved by particular conditions in a laboratory setting could be transferred to a specific part of the outside world - the operating room-by recreating the same conditions on a larger scale. ${ }^{63}$ The detailed instructions for controlling even the

Royal Victoria Hospital, see note 29 above. Direct current was used in many parts of the hospital until 1954.

${ }^{60}$ Ibid.

${ }^{61}$ See note 6 above.

${ }^{62}$ The translation is taken from Karel B Absolon, Mary J Absolon, and Ralph Zientek, 'From antisepsis to asepsis: Louis Pasteur's publication on "The germ theory and its application to medicine and surgery", Rev. Surg., 1970, 27: pp. 245-58. The original quote can be found in L Pasteur, La théorie des germes et ses applications à la médecine et à la chirurgie. Lecture faite à l' Académie de Médecine, Paris, G Masson 1878, pp. 16-17.

${ }^{63}$ This relationship between the laboratory and operating room is spelled out in another example by Gerard J Fitzgerald, 'Constructing the cradle: instrumental and architectural responses to airborn infection, 1935-45', unpublished paper presented at 'Form and Function: The Hospital', 3rd international conference of the International Network for the History of Hospitals, Montreal, 21 June 2003. 


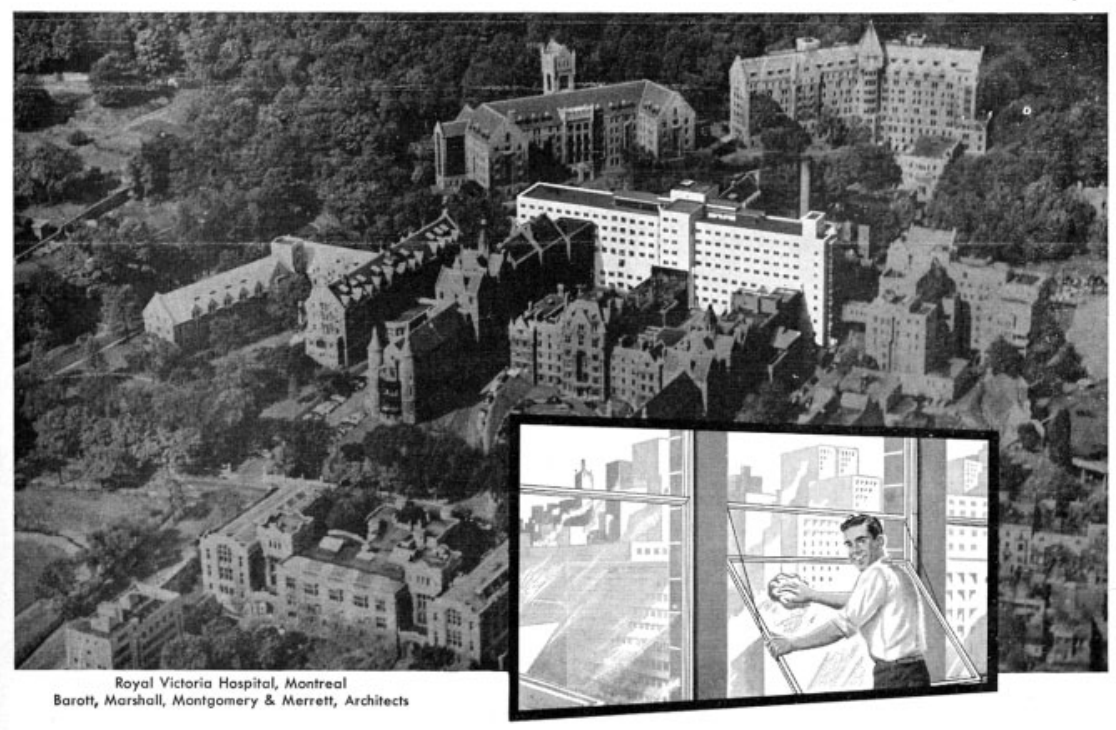

\section{another fine hospital selects Clerk windows}

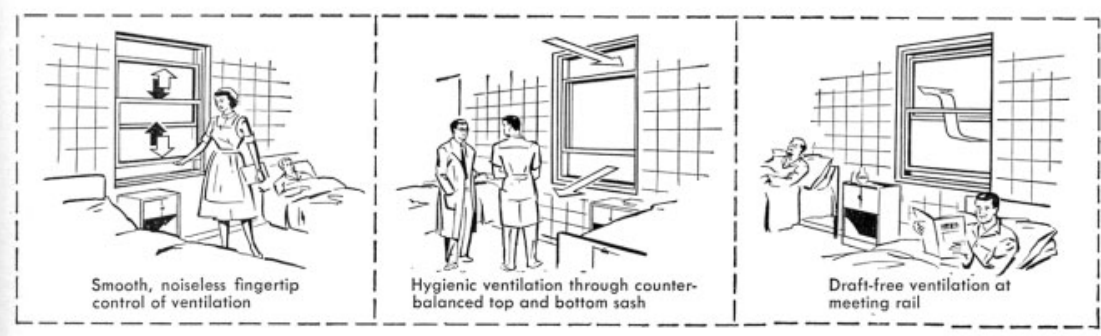

When planning new buildings or expanding present facilities, exacting hospitals find CLERK windows the only possible selection. Reversible sashes, originated by CLERK, permit easy, safe and economical cleaning from inside. CLERK windows are equipped with Pressure Seal double glazing and exclusive high wool pile weatherstripping. These assure satisfactory operation at all temperatures and reduce maintenance and heating costs.

CLERK windows are precision made from quality materials - to perform smoothly and efficiently for the life of the building. No other window, foreign or domestic, can match them. Clerk Windows Limited, 1499 Bishop Street, Montreal 25, Canada.

CLERK Windows equal or exceed quality window specifications as to quality of materials, fabrication strength of sections and minimum air infiltration.

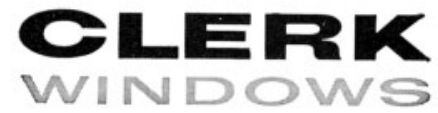

CLERK WINDOWS ARE AVAILABLE IN ALUMINUM, WOOd AND ALUMINUM-COVERED WOOD

Figure 11: This advertisement for Clerk windows from 1956 shows how the post-Second World War Surgical Wing functioned nearly as a backdrop against which the historic Victorian and interwar pavilions could be read (Canadian Hospital, May 1956, 33 (5): 55). 

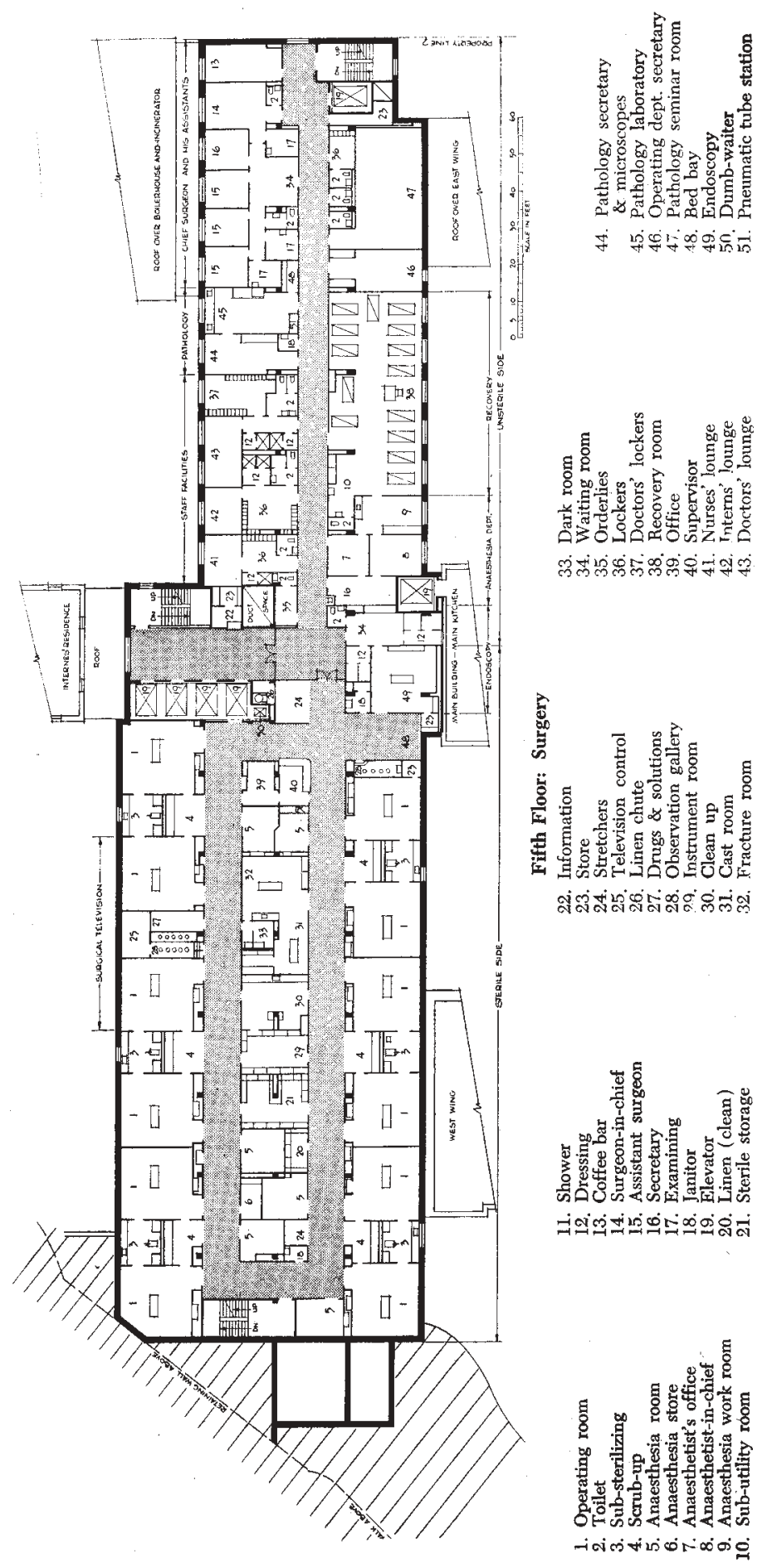

离

我

䨌

웡

芶

空.

$\dot{0}$

की

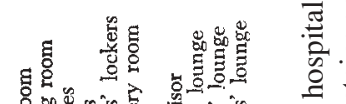

on

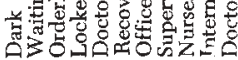

लंखिए户
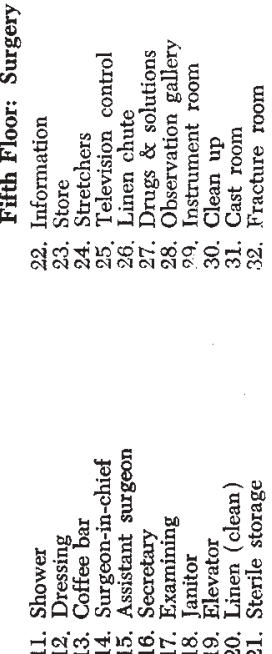

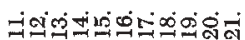

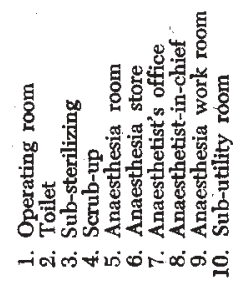

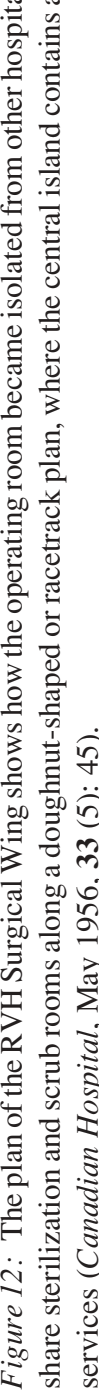


smallest bodily movement and gesture in the spaces designed for surgery ${ }^{64}$ are very similar to the detailed instructions on how to control one's movements during bacteriological experiments.

This principle of control is even more central in the third type of surgical environment, the completely isolated, mechanically illuminated, international-style surgical environment with even smaller, more laboratory-like, rooms. ${ }^{65}$ The monumental, ten-storey, 375 feet long Surgical Wing of 1955 added 274 beds as well as a complete floor of twelve operating rooms to the Royal Victoria Hospital. Designed by the Modernists Barott, Marshall, Montgomery \& Merrett of Montreal, the new Surgical Wing served as a symbolic and physical link of the main hospital to Stevens' Ross Memorial Pavilion, Penfield's Neurological Institute and Nobbs' Pathology Department. A splendid advertisement for Clerk windows from 1956 (Figure 11) shows how in terms of the overall site, the Surgical Wing functioned nearly as a white stage set or curtain against which the historic Victorian and interwar pavilions could be read.

In terms of its plan (Figure 12), the new Surgical Wing could not differ more from its predecessors. In contrast to Type I which was large, unique, transparent, and accessible from outside and naturally lit and ventilated, these Type III operating rooms are small, multiple, opaque, inaccessible, and mechanically lit and ventilated. Pairs of operating rooms share sterilization and scrub rooms; the arrangement is along a doughnut-shaped or racetrack plan, where the central island contains anaesthesia, storage, fracture, and other services. By the mid-twentieth century, it was the express aim of hospital architecture to "avoid all external influence on the working conditions inside the operating rooms". ${ }^{66}$ Operating rooms became isolated from their environment constituting an artificial space in which the surgeon's body was necessarily subjected to strict aseptic discipline. ${ }^{67}$ By the $1960 \mathrm{~s}$, the operating rooms accommodated only the highly sensitive surgical operations themselves. They were designed to meet the highest aseptic and hygienic standards, as well as providing appropriate lighting, quiet and favourable air and temperature conditions. For all other functions, operating rooms were allocated numerous annexes so that it became standard to refer to an "operating unit" as the core of every surgical department. ${ }^{68}$ Operating rooms became (and look) increasingly more like laboratories than like living rooms or theatres (they are in a sense highly artificialized rooms). ${ }^{69}$ Like laboratories, they are isolated from the rest of the world, spatially as well as in terms of access, and extremely clean-a quality, by the way, which can, in light of Mary Douglas's Purity and Danger, be interpreted as a special type of control. ${ }^{70}$

\footnotetext{
${ }^{64}$ For example, Kirschner, op. cit., note 24 above, pp. 263-71. On the "aseptic disciplining of the surgeon-body", see Hirschauer, op. cit., note 49 above, p. 286.

${ }^{65}$ Wangensteen and Wangensteen, op. cit., note 1 above, p. 465-70.

${ }^{66}$ Donzé, op. cit., note 9 above, p. 113.

${ }^{67}$ Hirschauer, op. cit., note 49 above, pp. 283-90.

${ }^{68}$ Mörgeli, op. cit., note 1 above, p. 254.
}

\footnotetext{
${ }^{69} \mathrm{We}$ are grateful to one of the anonymous reviewers who suggests that hospital laboratories may also have changed during this time period, perhaps becoming more like industrial laboratories or other workplaces.

${ }^{70}$ Mary Douglas, Purity and danger: an analysis of the concepts of pollution and taboo, New York, Praeger, 1966.
} 


\section{Conclusion}

These changes in spatial arrangement, lighting, ventilation, and OR size symbolized the scientific character of modern surgery, tapping into the cultural power of modern science at a time when surgery came to be widely seen as a purely technical and scientific activity. ${ }^{71}$ In the words of the medical historian Christopher Lawrence, "in surgery the fiction that medicine had nothing to do with politics reached its purest expression. Surgical intervention could be represented as the inevitable, scientific solution to disease, in comparison to which the alternative solutions seemed inferior". ${ }^{72}$

Scientific and surgical spaces intersected, we think, at the end of a gradual process of convergence. Surgery in our so-called Type I surgical space, a theatre, was theatrical. It had elements of a show, a performance, a process to be observed, material evidence of which can be seen in the open access to the space and the surgical theatre's carefully designed banked seating. Surgery in our so-called Type III surgical space, a laboratory-inspired room, was something else entirely. Rather than a performance in itself, surgery by the 1950s was less of a spectacle and more concerned with replicability, reliability, and control. Material evidence of this change is in the smallness, the exclusivity of the space, and a strict code of behaviour, modelled on the scientific laboratory.

\footnotetext{
${ }^{71}$ In the popular imagination as testified by the postwar media, however, surgery remained daring, heroic and manly. We are grateful to one of the journal's reviewers for noting this point.
}

\footnotetext{
${ }^{72}$ Christopher Lawrence, 'Democratic, divine and heroic: the history and historiography of surgery', in Lawrence (ed.), op. cit., note 2 above, pp. 1-47, on p. 32 .
} 